\title{
Water management problems related major reservoirs and irrigation systems in Polonnaruwa District, Sri lanka
}

\author{
DOI: $10.46932 / \mathrm{sjjdv} 1 \mathrm{n} 4-013$
}

Received in: August 1st, 2020

Accepted in: September 30th, 2020

\author{
Ranjana U K Piyadasa \\ Department of Environmental Technology, University of Colombo, Sri Lanka \\ E-mail: ranjana@et.cmb.ac.lk \\ Senarathne S.R.Achala.S. \\ Faculty of Graduate Studies, University of Colombo, Colombo, Sri Lanka \\ E-mail: achalasenarathne@gmail.com
}

\begin{abstract}
Water is a scarce resource in the dry zone of Sri Lanka and it is a major problem faced by the cultivators in the area. Since their cultivations totally depend on irrigation water every possible effort should be put in order to optimize the water usage to achieve increased crop production. Recent reports on water management activities of several irrigation schemes in the Dry Zone indicates, that the water distribution is not meeting the demands of farmers in terms of adequacy, reliability and timelines. Further it was said that there is considerable potential to increase paddy field in this system through improved irrigation water management, especially by efficient irrigation scheduling. The study intends to find out the annual statement of reservoir replenishment and behaviour is monthly analysed about reservoirs condition by Irrigation Department and recorded below data to statements for the water - year ending the month by month in orderly. It includes rainfall on catchment, area irrigated, water area, yield from catchment, issues from sluices, discharge over spills, change in reservoir storage, vapour-seepage loss, reservoir storage, depth at lowest sluice. And also this study identified above conditions and water management problems related ParakramaSamudraya, Giritale, Minneriya and Kaudulla major reservoirs in Polonnaruwa District. The greater part of the irrigated rice area is in the dry zone and the water availability there is less than that in others areas. Additionally, competition from domestic and industrial sectors will also increase. Therefore, water scarcities in the dry zone will have a severe impact on meeting the additional food requirements of the increasing population. In this respect, it is of vital importance to understand the regional scarcities of water and their impact on future food production.
\end{abstract}

Key words: catchment, irrigation, vapour-seepage loss, reservoir storage, water management

\section{INTRODUCTION}

Reservoir is major of the Sri Lankan historical village. Especially rainfall water or excess water is stored and distribute irrigation water within water shortage period using canal system by the reservoir. Sri Lankan villagers or farmers venerate to the reservoir like gods. "Water is a finite resource and natural gift. It is the most abundant environmental resource covering more than $70 \%$ of the Earth surface" (Gooneratne, 1990)[3]. Sri Lanka experiences high seasonal and spatial variations in rainfall due to the monsoonal climatic pattern. In here, Major reservoirs in Polonnaruwa District spill over in 
during northeast monsoon from October to March. Therefore, large quantity of water is over fold thought the spill in maha season at the same time poor farmers discharge irrigation water from these reservoirs in mahaseason. And also, people in Polonnaruwa District face water shortage time period couldn't fulfill agricultural practices in yala season for their cultivation. Most people couldn'table to get harvest and most people didn't follow that method in water shortage period. At the present, farmers have given up traditional water management methods to receive irrigation water for paddy lands. And also canal system has changed for their self needs by farmers. Like these problems have risen within distribution of irrigation water related toPrakramaSamudra, Girtale, Minneiya, Kaudulla major reservoirs in the Polonnaruwa District.

Polonnaruwa district is mainly covered by Anuradhapura, Mathale and Trincomalee districts. Out of these three districts only one is in the hill country and the other two areas in the dry zone low country area.The North-east monsoon rainfall is the main monsoon rainfall received by this region. It is from October to March and has a probability of getting over $2500 \mathrm{~mm}$ of rainfall for this area. Therefore, in maha season has arisen when the reservoirs are overflows. Polonnaruwa district is also situated in part of Mahaweli river basin. In Polonnaruwa district some areas can be identified as below 25m from mean sea level. As a result, the high incidence of flood in the maha season can be identified.This can be seen especially based in the Medirigiriya area called Kaudulla colony. The same situation can be seen in the divisional secretariats like Lankapura and Thamankaduwa.

However, in Polonnaruwa district, farmers are six or seven acre feet of water to cultivate and acre of paddy land. As a results of that the farmers use the same amount of water that is collected in the tanks during maha season. That is why arising shortage of water for cultivation during the yala season. A part from that, the farmers do not utilize rain water for their basic land preparation is more common situation in this district. Also no matter how many government institutions educate farmers about this, they do not understand the situation. Therefore, the farmers face a severe water shortage during the yala season. Another special feature of that farmers who cultivate under this tanks is they proper paddy cultivation in both season. During the yala season, farmers trend to grow paddy and there is no focus on other field crops. Therefore, the objective of this study is to identify and address the issue that arisen water management of paddy cultivation in Polonnaruwa district. It is expected to study the management of water in downstream of major tanks in Polonnaruwasuch as ParakckramaSamuddra, Minneriya, Girithale and Kaudulla.

And also, Excess irrigation or rainfall water effect to cultivation system and agrarian wells not enough to supply water for cultivation in irrigation water shortage time period. When discharge irrigation water rapidly without standard of discharging irrigation water from these reservoirs. That 
mostly affect to paddy cultivation. Within this study considered by Researchercontribution of farmers, water distributors, agrarian officers and procedures of the Agrarian Organizations, Irrigation Offices, Kanna Meetings and Water Management Committees to identify water management problems.

\section{LITERATURE REVIEW}

A water molecule consists of an oxygen atom bounded to two hydrogen atoms. The structure of the water molecule is determined by the electron configuration around the oxygen atom. Water is basically formed by cooling of the air. That's result decrease in temperature up to the minimum level that air can hold. The amount of water losses by evaporation is similar to the amount of water received by rainfall. That is actual situation, called evapotranspiration. Rainfall itself, surface water, storage water, soil water, channels, rivers and streams, lakes, ground water, springs and water falls could be included to the term. The forms such as rain water, ground water, soil water, stream and rivers are originally natural, while other such as storage reservoirs, canals and irrigation channels are artificial.(Bandaranayake 2007)[1] History shows that people who settled in the Dry Zone constructed earthen bunds across the natural drainage basin to collect runoff water. Nearly $70 \%$ of the annual total rainfall in the Dry Zone occurs during the Northeast Monsoon from late October to January, the main rainy season. (Somasiri 1978)[6]. The practice of bethma, as it was observed in the North Central Province before the British administration got established in the villages: A portion of the field of suitable size is selected and all the rest is abandoned. The selected portion is now divided into the same number of shares in the whole field...The persons whose land is thus selected don't get larger allurements than others...Each bethma arrangement is binding only for one crop and when it has been removed matters revert to their original position. (Brodie 1856)[2]. The Government of Sri Lanka has identified the need for a comprehensive policy revision in the water sector and is attempting to develop a new set of policies. Policymakers are working to facilitate new investments, promote data and information sharing, and move towards Integrated Water Resources Management in recognition of the key role that water will play in the growth of the economy.((IWMI), Sri Lanka: issues and opportunities for investment 2010)[5], Piyadasa (2011)[6] .A comprehensive study of landholding system in a Dry Zone purana village was made by Leach in 1954. Although the results of this study can't by any means be generalized for the Dry Zone as a whole, they indicate some general patterns observable in most villages. Ievers, in his Manual of the North Central Province (1899) provides a vivid picture of the layout of a traditional paddy system.(Ievers 1899)[4] . The decline in the system of water management and the deterioration of the agricultural production base of the small tank-based villages are the consequences of a breakdown in the organization of tank management alone. While this has been the 
immediate cause, there are also other factors accounting for this situation. They are linked to the issues of land tenure and technology(Gooneratne 1980)[3] .

\section{STUDY AREA}

Polonnaruwa District is governed by the District Secretary or the Government Agent who reports to the Secretary, Public Administration of the Central Government. The district is comprised of 7 Divisional Secretary Divisions and 295 GramaSewaDivisions. There are 657 villages under Polonnaruwa District. Polonnaruwa is $5 \%$ of the total land area of Sri Lanka and $31 \%$ of the total land area of the North Central Province. There are 07 PradesheeyaSabhas, which are namely, Hingurakgoda, Medirigiriya, Lankapura, Thamankaduwa, Elahera, Dimbulagala and Welikanda in the District of Polonnaruwa and 87 members are chosen by the people for these PradesheeyaSabhas.Polonnaruwa district is composed of 05 Electoral Districts and is represented by 05 members in the Parliament of the Central Government.

Figure1: Study on the location of four major reservoirs in Polonnaruwa District

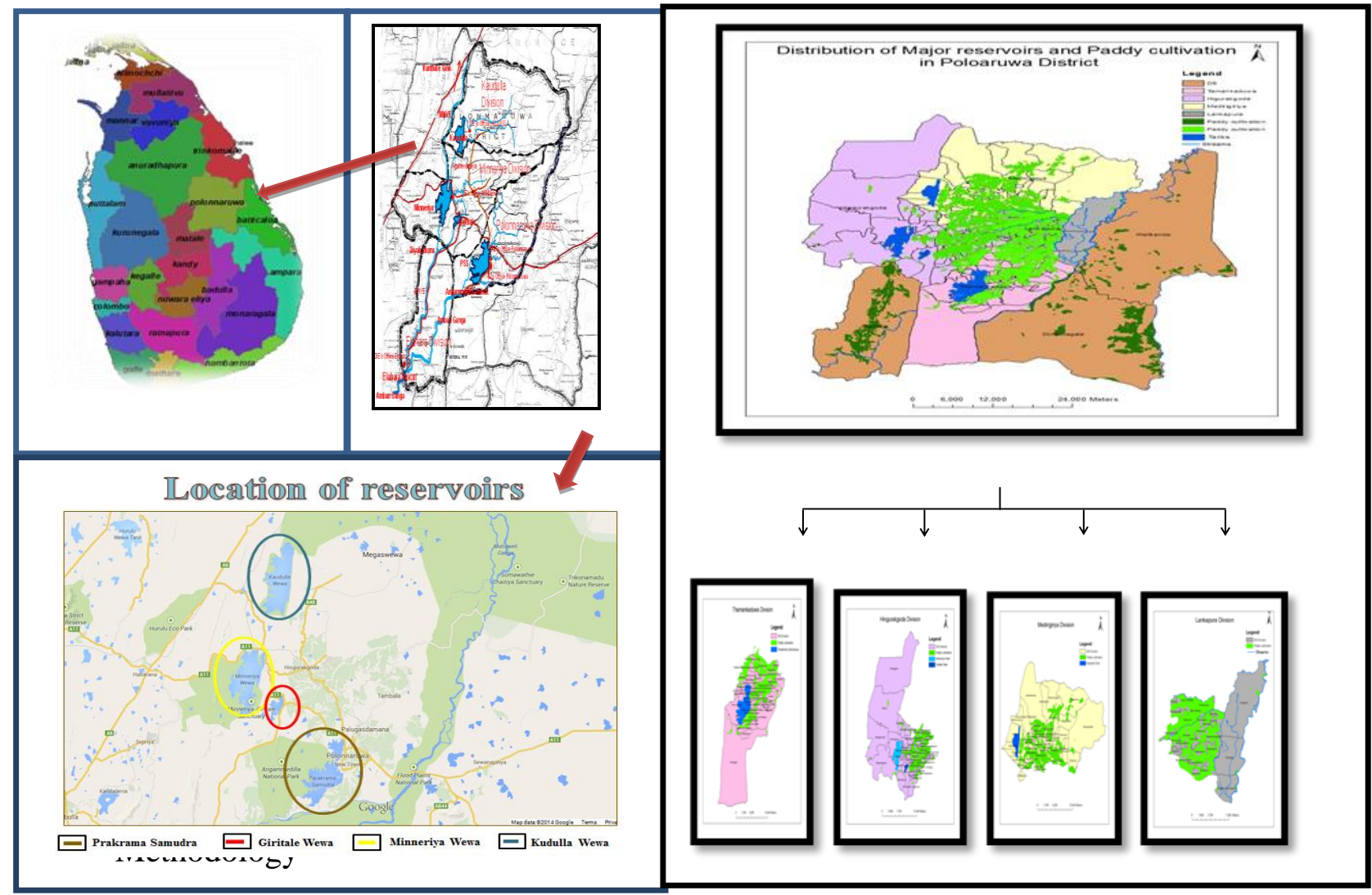

Hundred (100) randomly picked sampling resident farmers around the reservoir by reservoir from Questionnaires. They were obtained from farmers by questionnaires. Simple Random Sample method was best suited to collect relevant data from study area. Four divisions selected to collect data in 
Polonnaruwa District. Reason for that, study followed to examine associated water management problems of major reservoirs. Collected data present to examine reasons for Irrigated water usage for paddy cultivation and day today activities of farmer's behavior from field observation. Sample size explanted mostly affected GN:5 in Medirigiriya Division by 23\% sample size,mostly affected GN:8 in Lankapura Division by 26\% sample size and mostly affected GN:7 in Hingurakgoda Division by $20 \%$ sample size of the research. Consider to collect data from three divisions of located major reservoirs, namely Thamankaduwa, Hingurakgoda and Medirigiriya. And also, it's most affected division, name: Lankapura. According to numbers of agrarian families in four divisions, primary data collected from fifty questionnaires separately. Secondary data collected through annual statements of reservoir replenishment reports from Irrigation Department and statistical reports of rainfall, land use, paddy harvested and project reports, documents, Journals, Internet, Mahaweli reports, books and articles.

\section{RESULT AND DISCUSSION}

Comparison of variation of irrigation behavior in major reservoirs due to water management problems

Figure 2: Water Usage - Yala/Maha

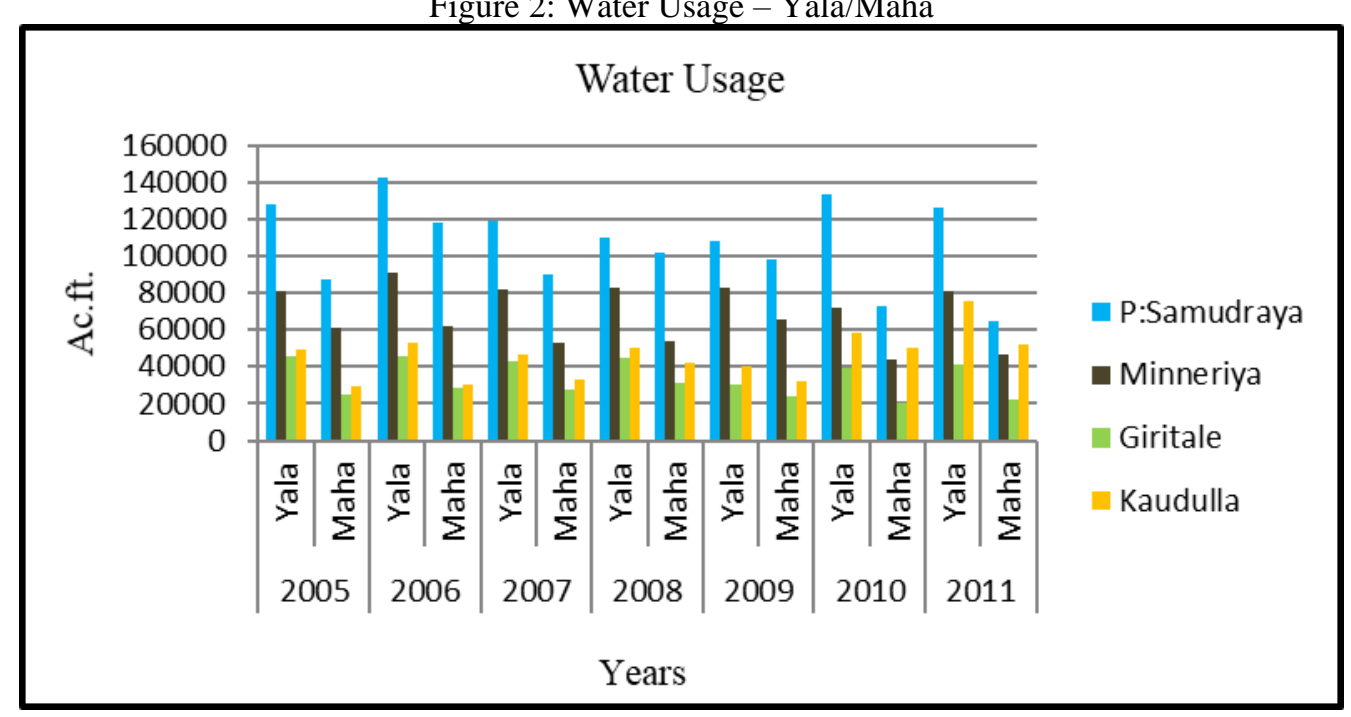

Source: Head Office of the Director of Irrigation Polonnaruwa

Waterusage of these reservoirs has been increased in Yala season than Maha season. That reason for, if there was high water capacity level in Maha season couldn'table to use for cultivation practices. That's results occurring flood. According to this compared results, water usage of ParakramaSamudraya was in high level. Giritale was in low level according to same results. 
Figure 3: Excess water usage - Yala/Maha

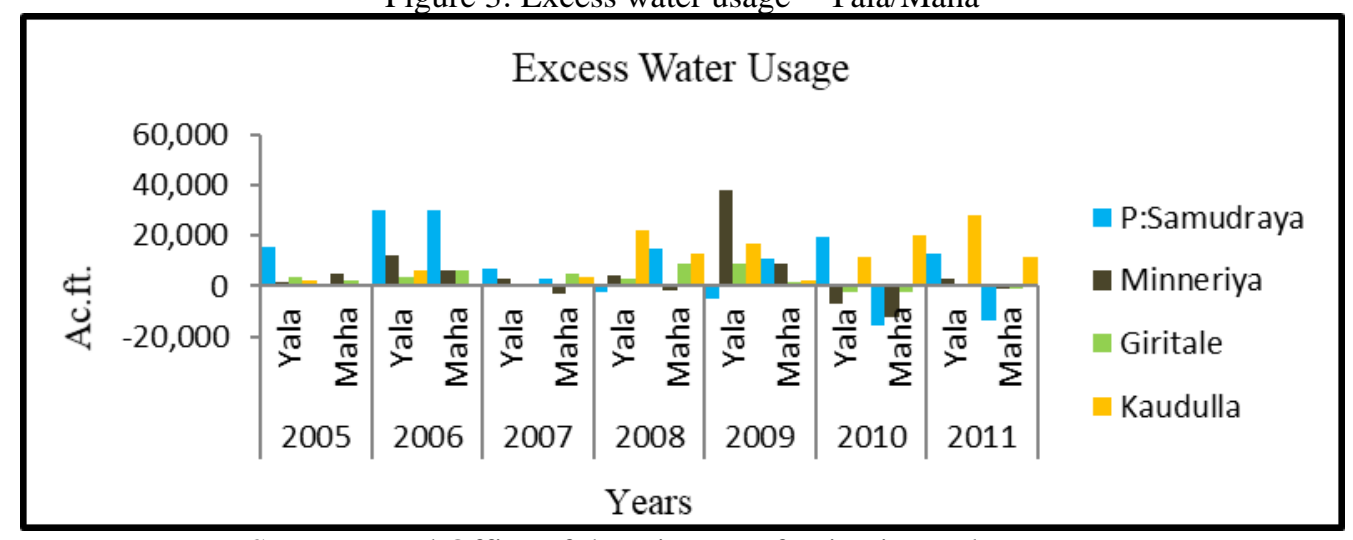

Source: Head Office of the Director of Irrigation Polonnaruwa

Excess water usage of Minneriyareseroivr was in maximum level in 2009- Yala than other reservoirs. That's result of PararamaSamudraya was in low level in 2010 - Maha.

Figure 4: Area cultivated around reservoirs - Yala/Maha

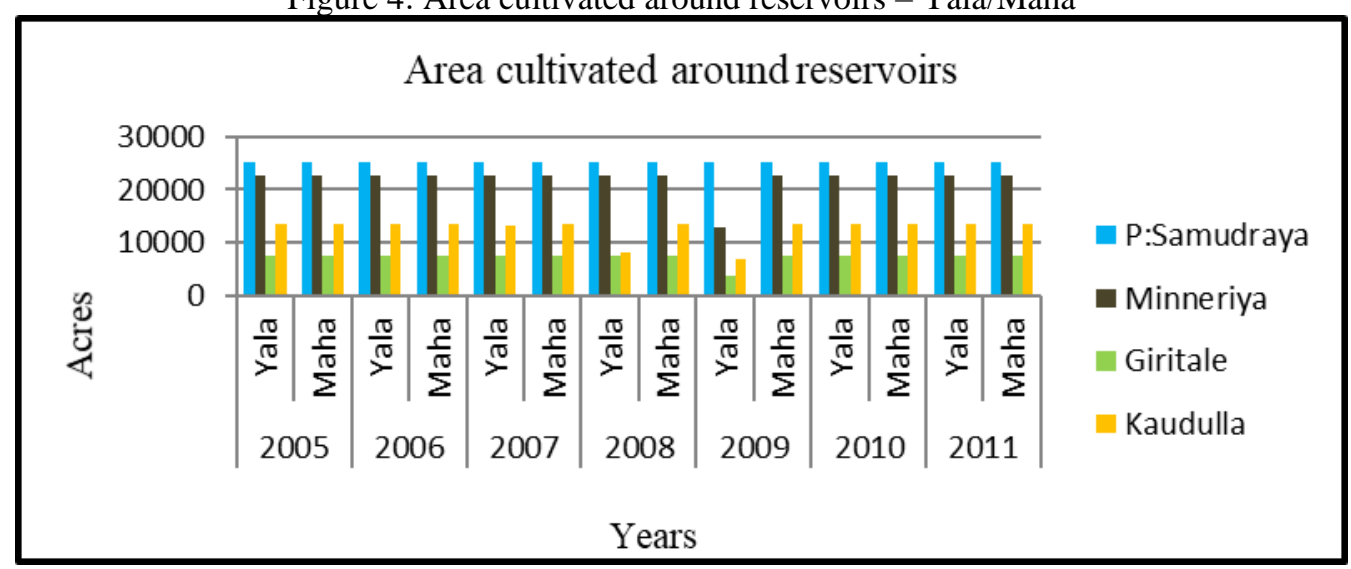

Source: Head Office of the Director of Irrigation Polonnaruwa

Area cultivated of Giritale reservoir was in low level than other reservoirs in both seasons. That's result of ParakramaSamudra was in maximum level than other reservoirs in both seasons. In 2005-2011 mainly water management problems have arisen in Giritale and Kaudulla reservoirs than other reservoirs. 
Figure 5: Average Duty in Reseoirs- Yala/Maha

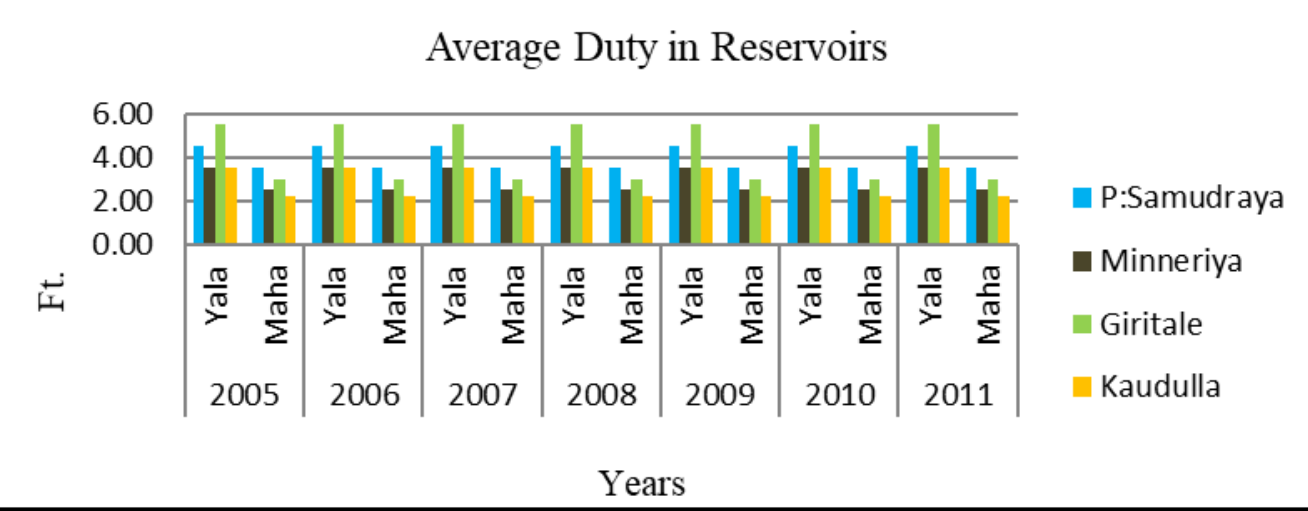

Source: Head Office of the Director of Irrigation Polonnaruwa

Average duty of Giritale reservoir was in high level than other reservoirs in both seasons. That's result of Kaudulla reservoir was in low level than other reservoirs in both seasons.

Figure 6: Water Duty in Reservoirs - Yala/Maha

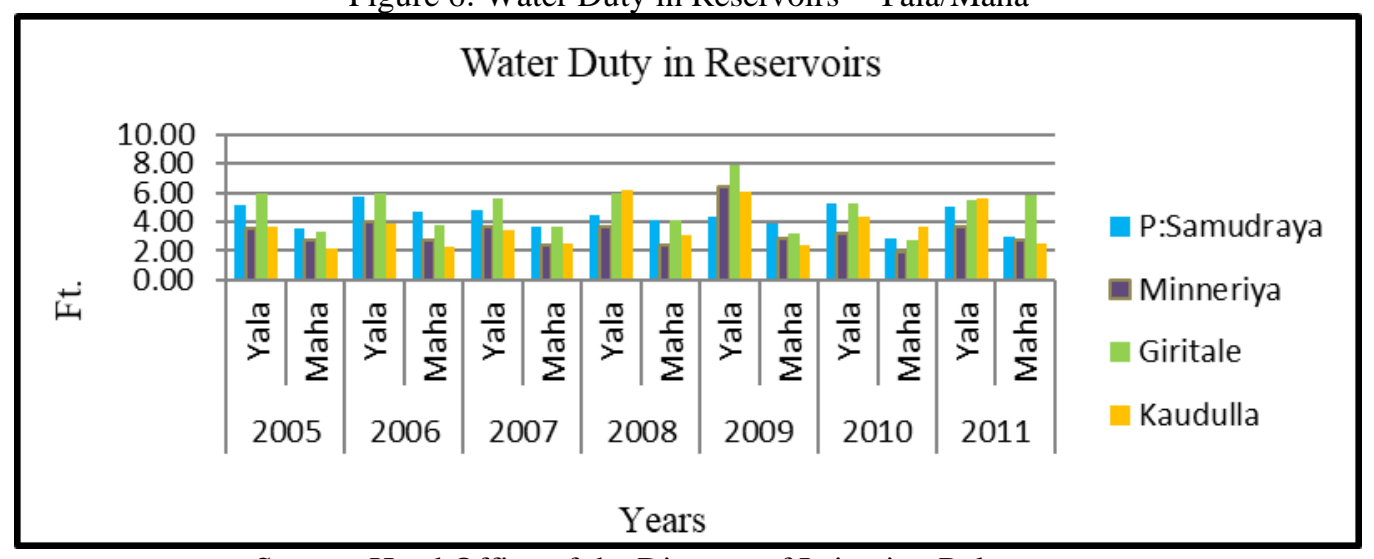

Source: Head Office of the Director of Irrigation Polonnaruwa

Water duty of these reservoirs was in reduction level in Maha season than Yala season. That's was affected to arise irrigation water shortage periods in Yalaseason. It's supported for paddy cultivation and low harvested extent. High water duty supports for high yields of paddy cultivation.

Figure 7 : Summary of the water behavior and reasons

\begin{tabular}{|c|c|c|c|c|c|c|c|c|c|}
\hline \multirow{2}{*}{$\begin{array}{l}\text { Name of } \\
\text { the } \\
\text { reservoir }\end{array}$} & \multicolumn{7}{|c|}{ Behavior of the Reservoir } & \multirow[b]{2}{*}{ Reasons } & \multirow[b]{2}{*}{ Problems } \\
\hline & $\begin{array}{c}\text { Water } \\
\text { capacity } \\
\text { beginnin } \\
\text { g of } \\
\text { season }\end{array}$ & $\begin{array}{c}\text { Wate } \\
\text { r } \\
\text { usage }\end{array}$ & $\begin{array}{c}\text { Excess } \\
\text { water } \\
\text { usage }\end{array}$ & $\begin{array}{c}\text { Area } \\
\text { cultivate } \\
\text { d }\end{array}$ & $\begin{array}{c}\text { Rainfal } \\
1\end{array}$ & $\begin{array}{l}\text { Aver } \\
\text { age } \\
\text { duty }\end{array}$ & $\begin{array}{c}\text { Wate } \\
\text { r } \\
\text { duty }\end{array}$ & & \\
\hline $\begin{array}{c}\text { Parakra } \\
\text { maSamu } \\
\text { draya }\end{array}$ & $\begin{array}{c}\text { High } \\
>25000 \\
\text { Ac.ft }\end{array}$ & $\begin{array}{c}\text { High } \\
>350 \\
00 \\
\text { Ac.ft }\end{array}$ & $\begin{array}{c}\text { Low } \\
<5000 \\
\text { Ac.ft }\end{array}$ & $\begin{array}{c}\text { High } \\
>17500 \\
\text { Acre }\end{array}$ & $\begin{array}{l}\text { High } \\
>750 \\
\mathrm{~mm}\end{array}$ & $\begin{array}{l}\text { High } \\
>2.5 \\
\text { Ft. }\end{array}$ & $\begin{array}{c}\text { Low } \\
<2.00 \\
\mathrm{Ft}\end{array}$ & $\begin{array}{l}\text { Continuou } \\
\text { sly water } \\
\text { issue } \\
\text { Lack of } \\
\text { farmers } \\
\text { attention }\end{array}$ & $\begin{array}{c}\text { Lack of } \\
\text { water } \\
\text { manageme } \\
\text { nt }\end{array}$ \\
\hline
\end{tabular}




\begin{tabular}{|c|c|c|c|c|c|c|c|c|c|}
\hline Giritale & $\begin{array}{c}\text { Low } \\
<20000 \\
\text { Ac.ft }\end{array}$ & $\begin{array}{c}\text { Low } \\
<250 \\
00 \\
\text { Ac.ft }\end{array}$ & $\begin{array}{c}\text { High } \\
>1000 \\
0 \text { Ac.ft }\end{array}$ & $\begin{array}{l}\text { Low } \\
<7500 \\
\text { Acre }\end{array}$ & $\begin{array}{l}\text { Low } \\
<500 \\
\mathrm{~mm}\end{array}$ & $\begin{array}{c}\text { High } \\
>2.5 \\
\text { Ft. }\end{array}$ & $\begin{array}{c}\text { High } \\
>4.00 \\
\text { Ft }\end{array}$ & $\begin{array}{l}\text { Low water } \\
\text { capacity } \\
\text { and } \\
\text { catchment } \\
\text { area }\end{array}$ & $\begin{array}{c}\text { Arisen } \\
\text { water } \\
\text { shortage } \\
\text { periods }\end{array}$ \\
\hline $\begin{array}{c}\text { Minneriy } \\
\text { a }\end{array}$ & $\begin{array}{c}\text { High } \\
>25000 \\
\text { Ac.ft }\end{array}$ & $\begin{array}{c}\text { High } \\
>350 \\
00 \\
\text { Ac.ft }\end{array}$ & $\begin{array}{c}\text { Low } \\
<5000 \\
\text { Ac.ft }\end{array}$ & $\begin{array}{c}\text { High } \\
>17500 \\
\text { Acre }\end{array}$ & $\begin{array}{c}\text { High } \\
>750 \\
\mathrm{~mm}\end{array}$ & $\begin{array}{c}\text { Low } \\
<2.5 \\
\text { Ft. }\end{array}$ & $\begin{array}{c}\text { Low } \\
<2.00 \\
\mathrm{Ft}\end{array}$ & $\begin{array}{l}\text { Moderate } \\
\text { level of } \\
\text { water } \\
\text { issue and } \\
\text { inflow }\end{array}$ & $\begin{array}{l}\text { Occurring } \\
\text { flood }\end{array}$ \\
\hline Kaudulla & $\begin{array}{c}\text { Low } \\
<20000 \\
\text { Ac.ft }\end{array}$ & $\begin{array}{c}\text { Low } \\
\text { Low } \\
<250 \\
00 \\
\text { Ac.ft }\end{array}$ & $\begin{array}{c}\text { High } \\
>1000 \\
0 \text { Ac.ft }\end{array}$ & $\begin{array}{c}\text { Low } \\
<7500 \\
\text { Acre }\end{array}$ & $\begin{array}{c}\text { Low } \\
<500 \\
\mathrm{~mm}\end{array}$ & $\begin{array}{c}\text { Low } \\
<2.5 \\
\text { Ft. }\end{array}$ & $\begin{array}{c}\text { High } \\
>4.00 \\
t\end{array}$ & $\begin{array}{c}\text { High } \\
\text { evaporatio } \\
\mathrm{n} \text { and low } \\
\text { rainfall }\end{array}$ & $\begin{array}{c}\text { Occurring } \\
\text { flood and } \\
\text { drough }\end{array}$ \\
\hline
\end{tabular}

Source: Field Sample Survey: 2019

Activities of Agrarian Organization, Water Management Committees and decisions of Kanna meeti

Comparison of Agrarian Organizations' operation systems have been in normal level than other committees. Farmers properly maintain canal system and paddy lands than Officers of Irrigation Departments. They have able to get solutions for water management problems. Because they identify problems related irrigation water management and cultivation practices. Decisions of Kanna meetings have in good level, but operation systems of Water Management Committees in informal level.

Figure 8: Activities of Agrarian Organization, Water Management Committees and decisions of Kanna meetings

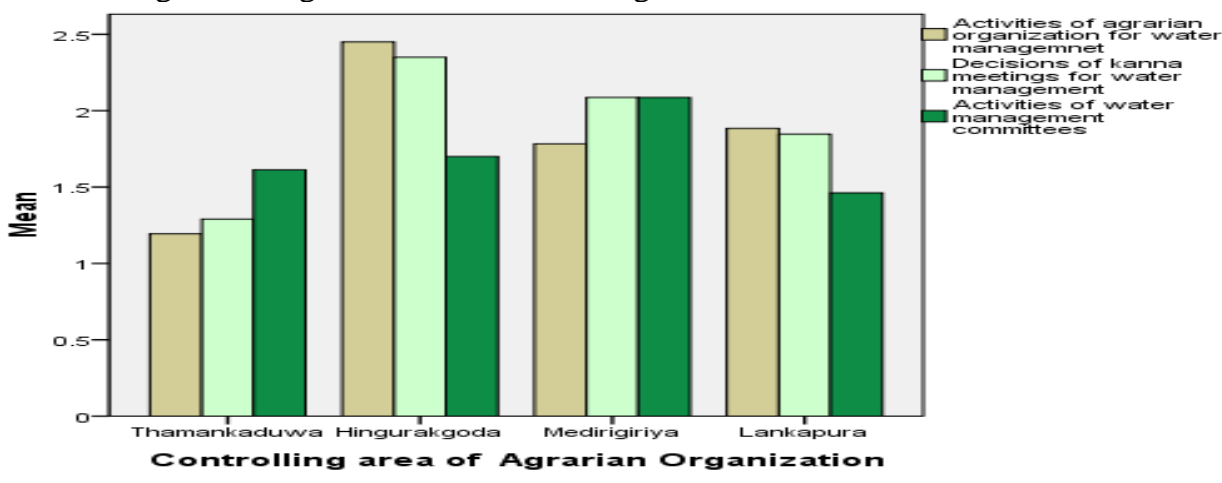

Source: Field Sample Survey: 2019

\section{CONCLUSION}

Paddy cultivation depends on irrigation water of the reservoir. Parakrama Samudraya, Giritale, Minneriya and Kaudulla major reservoirs are heart of the Polonnaruwa District. The main purpose of this study also studying and identifying water management problems related these reservoirs.First chapter discussed the formation of the research and how organize the time, data and methodology. Second chapter comprised with theoretical background to review about behavior of the reservoirs based 
on water management. In the third chapter discussed the formation of the research environment. Fourth chapter was analyzed primary and secondary data relevant water management problems related major reservoirs. Like primary data, some discussions of consulters and farmers considered to examine associated water management problems major reservoirs within study area.Irrigation Department has't proper implementation program for irrigation water distribution and maintenance of canal systems.In this chapter analyzed comparisons of these reservoirs to identify high affect for water waste in paddy cultivation. Rainfall of ParakramaSamudraya has been increased than other tanks in Maha season. But it decreased in Yala season. Rainfall of Giritale, Minneriya and Kaudulla has been increased in Yala season than Maha season.In Maha season, maximum quantity of paddy lands cultivates under irrigation water of the tank. But in Yala season, minimum quantity of paddy lands cultivates under irrigation water of the tank. Farmers decided quantity of cultivated lands from their experiences. Technologically, to decide this value should occur water balance. Consider tank water balance, catmint water balance and field water balance. When consider irrigation and water management with nutrition cycle as productivity, stability, sustainability and equity.

\section{ACKNOWLEDGEMENTS}

This research intends to find out the annual statement of reservoir replenishment and behavior is monthly analysed about reservoirs conditions and recorded below data to statements for the water - year ending the month by month in orderlyfrom Irrigation Department, Colombo 


\section{REFERENCES}

1) Bandaranayake, G.M. Water Resources Study. Nugegoda: Godage International Publishers (Pvt) Ltd, 2007.

2) Brodie, A.O.Royal Asiatic Society Journal (Ceylon Branch). Vol.3. 1856.

3) Gooneratne, W.and Hirashima,S. Irrigation and Water Management in Asia. Edited by W.and Hirashima,S. Gooneratne. New Delhi: Sterling Publishers Private Limited, 1990.

4) Ievers, R.W. Manual of the North Central Province . Colombo, 1899.

5) Institute, (IWMI) International Water Management. "Sri Lanka: issues and opportunities for investment." Colombo, 2010.

6) Piyadasa, R.U.K., (2011); Impacts of Climate Changes on Water resources in Sri Lanka and Currunt Adaptation Measures, In proceedings of the International Symposium on Promoting Synergies Among Adaptation Networks in the Asia-Pasific Region, Ibaraki University, Mito, Japan Abstract Volume, January 17, 2011, Japan (Pg 45-46)

7) Somasiri, S. Efficient utilization of physical agricultural resources in the Dry Zone of Sri Lanka. 1978. 